\title{
Complications after endovascular repair of acute symptomatic and chronic expanding Stanford type B aortic dissections
}

Dittmar Böckler, MD, ${ }^{a}$ Hardy Schumacher, MD, PhD, ${ }^{a}$ Marika Ganten, MD, ${ }^{b}$ Hendrik von Tengg-Kobligk, MD, ${ }^{c}$ Matthias Schwarzbach, MD, PhD, ${ }^{a}$ Christian Fink, MD, ${ }^{\mathrm{c}}$ Hans-Ulrich Kauczor, MD, PhD, ${ }^{\mathrm{c}}$ Hubert Bardenheuer, MD, PhD, and Jens-Rainer Allenberg, MD, $\mathrm{PhD}^{\mathrm{a}}$

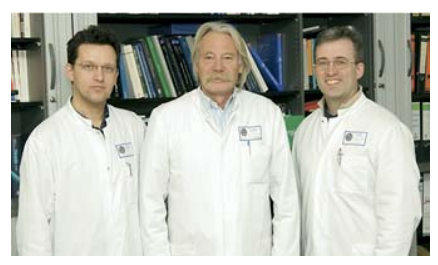

Drs Böckler, Allenberg, and Schumacher (left to right)

Supplemental material is available online.
From the Departments of Vascular and Endovascular Surgery, ${ }^{\mathrm{a}}$ Radiodiagnostics, ${ }^{\mathrm{b}}$ and Anaesthesiology, ${ }^{\mathrm{d}}$ Ruprecht-Karls University Heidelberg, and Department of Radiology, ${ }^{\mathrm{c}}$ German Cancer Research Center (DKFZ), Heidelberg, Germany.

Hardy Schumacher reports receiving a consulting fee and payment for a workshop from WL Gore \& Associates.

Received for publication April 24, 2005; revisions received Jan 14, 2006; accepted for publication Feb 21, 2006.

Address for reprints: Dittmar Böckler, MD, Abteilung für Gefäßchirurgie, Chirurgische Universitätsklinik Heidelberg, Im Neuenheimer Feld 110, 69120 Heidelberg Germany (E-mail: dittmar_boeckler@med.uniheidelberg.de).

J Thorac Cardiovasc Surg 2006;132:361-8

$0022-5223 / \$ 32.00$

Copyright (C) 2006 by The American Association for Thoracic Surgery

doi:10.1016/j.jtcvs.2006.02.056
Objective: To outline the complications after endovascular repair in patients with acute symptomatic and chronic expanding Stanford type B aortic dissections.

Methods: Between 1997 and 2004, of 125 patients with acute and chronic aortic type B dissections, 88 were treated conservatively. Thirty-seven patients ( 29 male, mean age 58 years, range 30-82 years) underwent endovascular repair (30\%) using 44 stent grafts of 3 different designs: Excluder (W. L. Gore \& Associates, Inc, Flagstaff, Ariz), Talent (Medtronic Vascular, Santa Rosa, Calif), and Endofit (Endomed, Inc, Phoenix, Ariz). Indications for treatment were acute symptomatic type B dissection in 15 patients, chronic expanding aortic dissection greater than $55 \mathrm{~mm}$ in 14, rupture in 3, and simultaneous type A repair in 5 patients. Twenty-two operations were performed on an emergency basis. Patient characteristics, procedural variables, outcome, and complications were prospectively recorded. All patients underwent follow-up by computed tomography before discharge, at 6 and 12 months, and annually thereafter (mean follow-up: 24 months).

Results: Correct deployment was achieved in $97 \%$ of cases. There were no instances of primary conversion, paraplegia, or stroke. Complete false lumen thrombosis was observed in 11 patients (44\%). Perioperative complication rate was $22 \%$. Thirty-day mortality rate in acute and chronic dissections was $19 \%$ and $0 \%$, respectively. Freedom from aortic reintervention was $81 \%, 73 \%$, and $68 \%$, freedom from late rupture was $97 \%, 90 \%$, and $80 \%$, and overall success rate was $76 \%, 65 \%$, and $57 \%$ at 1,2 , and 5 years, respectively. Results for patients with chronic dissections are significantly $(P=.038)$ better than results in those with acute dissections.

Conclusions: Despite the minimally invasive approach, the complication and mortality rates for endovascular therapy of aortic dissections are still high. Frank reporting of these sequelae is if great importance to clarify the recent limitations of the method.

A ortic dissection is most often a catastrophic event which, if untreated, can be potentially life threatening. In a population-based longitudinal study, Meszaros and associates ${ }^{1}$ report mortality rates of acute untreated aortic dissection of $22.7 \%, 50 \%$, and $68 \%$ within 6 hours, 24 hours, and the first week, respectively. The International Registry of Acute Aortic Dissection (IRAD) study, with an overall mortality of $27.4 \%$, confirmed that aortic dissection is a lethal disease. ${ }^{2}$ Open surgical repair also is associated with high morbidity and mortality. ${ }^{3}$

The advent of endovascular prostheses to treat descending thoracic aortic lesions offers an alternative approach in patients with dissections and severe comorbidities who are poor candidates for open surgery. ${ }^{4,5}$ 


\author{
Abbreviations and Acronyms \\ $\mathrm{ABF}=$ aortobronchial fistula \\ $\mathrm{CEAD}=$ chronic expansive aortic dissection \\ $\mathrm{CT}=$ computed tomography \\ IRAD = International Registry of Acute Aortic \\ Dissection \\ TLC = true lumen collapse
}

However, endoluminal treatment is not without complications. $^{6-8}$ Therefore, it is vital to report considerable complication rates and the midterm outcome after endografting. Hence, this report describes a continuing singe-center experience with endoluminal stent-graft repair in acute complicated and chronic expanding aortic type B dissections, focusing on limitations and complications of endovascular management.

\section{Patients and Methods}

Between March 1997 and December 2004 (an 8-year period), 125 consecutive patients presented with acute and chronic Stanford type B dissections in our department. In all cases, diagnosis was confirmed with computed tomography (CT) or magnetic resonance imaging. Thereby, retrograde involvement of the ascending aorta and arch were excluded. Eighty-eight (70\%) were treated conservatively and were followed-up routinely by CT scan on an annual basis. Thirty-seven patients with aortic dissection underwent transluminal endovascular stent-graft placement.

\section{Patients}

Patient evaluation, selection, and endovascular procedures were performed by vascular surgeons. All patients with suitable aortic morphologic characteristics were offered a stent graft as our preferred alternative to open repair. Clinical characteristics, imaging, and procedural data were documented prospectively. Fifty-nine percent $(n=22)$ of all operations were emergency interventions.

For this study, the records of 29 men and 8 women (mean age 57 years, range 30-82 years) were reviewed. Patient characteristics, indications, stent-graft data, and results of treatment are summarized in Table E1. Fifteen patients had visceral, renal, or leg ischemia with true lumen collapse (TLC), and 3 had rupture of the false lumen (1 presenting with aortobronchial fistula $[\mathrm{ABF}] 2$ years after initial uncomplicated dissection). Fourteen patients had chronic expansive aortic dissection (CEAD) greater than $55 \mathrm{~mm}$ of maximum diameter. All patients treated on an emergency basis had some degree of chest pain as the first presenting symptom. Five patients were treated by endografting after type A dissection repair: 2 immediate repairs in cooperation with cardiac surgeons (2 antegrade deployments necessitated by bleeding at the distal anastomosis of the arch repair) and 3 staged procedures necessitated by TLC with malperfusion syndrome (1 visceral, 1 renal ischemia) and due to chronic aneurysmal expansion and consecutive infrarenal aortic rupture via transfemoral access.

\section{Pre-procedural Imaging}

All patients underwent spiral contrast-enhanced CT angiography with 3-mm slices and 3-dimensional reconstruction (Leonardo Workstation; Siemens AG, Erlangen, Germany; and Vitrea 2 workstation; Vital Images, Inc, Plymouth, Minn). Entry site, intended landing zone and diameter, distribution of abdominal vessels, length of dissection, and involvement of iliac arteries to evaluate the suitability for vascular access were determined. Measuring of the aortic arch diameter and the proximal anchoring zone was performed in the so-called "centerline" at the work station. Owing to the fragility of the aortic wall, oversizing was performed very gently $(\sim 10 \%)$ and only self-expanding endografts were implanted.

\section{Device Details and Stent-Graft Placement}

Six patients received more than 1 stent graft system simultaneously. Five patients received 2 devices and 1 patient received 3 devices. In total, 44 stent graft systems were implanted: 34 Excluder thoracic endoprostheses (TAG; W. L. Gore \& Associates, Inc, Flagstaff, Ariz), 9 Talent endoluminal stent grafts (Medtronic Vascular, Santa Rosa, Calif), and 1 Endofit thoracic endoprosthesis (Endomed, Inc, Phoenix, Ariz) with lengths from 100 to $220 \mathrm{~mm}$ and diameters between 28 and $40 \mathrm{~mm}$. The median stent graftcovered aortic segment was $169 \mathrm{~mm}$ (range 100-220 mm). Two surgeons equally qualified in endovascular experience performed all endovascular procedures with the patients under general anesthesia in an operating theater equipped with fluoroscopic and angiographic capabilities (series 9800; OEC Medical Systems, Inc, Salt Lake City, Utah) and a carbon-fiber operating table. Each patient received single-shot antibiotic therapy and 3000 units of heparin intravenously. With the exception of 1 patient (No. 30: antegrade approach during aortic arch repair), vascular access was obtained in 29 patients via the common femoral artery and in 7 patients by implanting a temporary $10-\mathrm{mm}$ Dacron conduit to the common iliac artery because of small vessel size. The nondissected iliac/femoral artery, if iliac vessels were affected, was preferred for access. A 0.035-inch guide wire (Terumo, Frankfurt, Germany) was advanced and exchanged for a $7 \mathrm{~F}$ calibrated angiography catheter. Digital subtraction angiography was performed with apnea followed by manual injection of $20 \mathrm{~mL}$ of nonionic contrast medium (Iopamidol [Solutrast 300], Byk Gulden, Konstanz, Germany). The aortic arch was rotated to about $45^{\circ}$ in the left anterior oblique projection to adjust the parallax error for exact visualization of the proximal landing zones (minimum $15 \mathrm{~mm}$ ). A sheath (up to 26F) was inserted over the guide wire and exchanged with a 0.035-inch, 260-cm Amplatz Super Stiff guide wire (Boston Scientific, Ratlingen, Germany) and passed to the aortic arch. Temporary adenosine-induced cardiac arrest with an average dose of $60 \mathrm{mg}$ was used for precise endograft placement in 26 patients. Additionally, all patients were provided with external pacemakers. Ballooning was not performed. Transesophageal echocardiography was not used routinely during deployment, and there was no standby heart-lung machine. Completion angiography was performed to assess accurate placement and exclusion of the entry site of the dissection. Stent grafts were only deployed at the entry sites to depressurize the false lumen and to induce thrombosis. Stent grafting of longer aortic segments was avoided because of fear of paraplegia. To achieve a sufficient proximal anchoring zone in 
patients with CEAD and without any healthy landing zone, we performed one transposition of the left subclavian artery alone and polytetrafluoroethylene crossover bypass of both left common carotid and subclavian arteries in 2 patients before elective endografting.

\section{Follow-up}

Follow-up status between 1997 and 2004 is $100 \%$ complete and was performed in our department The follow-up protocol included postoperative contrast-enhanced CT scanning and plain chest radiography before hospital discharge, 6 months and 12 months after endografting, and annually thereafter. The mean follow-up is 24 months (range 0-56 months). Cause of death was obtained by medical reports or by contacting the primary care physician.

\section{Definitions}

By definition, acute type $\mathrm{B}$ dissection is present when diagnosis is made within 2 weeks after the initial onset of symptoms. Primary success was defined as insertion and accurate placement of the stent graft in the intended landing zone, successful immediate entry occlusion, and lack of immediate perioperative complications without any additional interventions. End points and criteria for late outcome were false lumen thrombosis of the thoracic aorta, lack of thoracic aorta expansion, and freedom from rupture. Endoleak is defined as radiologic evidence of blood flow outside the stent graft according to published guidelines, except persistent retrograde false lumen perfusion. ${ }^{9}$ Reintervention is defined as any need for surgical or endovascular intervention on the treated aortic segment during follow-up. Treatment failure was defined as proximal type I endoleak, perioperative death, aortic reintervention, dissection-related death, and all sudden unexplained late deaths during follow-up.

\section{Statistical Analysis}

Comparison of acute and chronic dissections was done by the Wilcoxon signed-rank test. Kaplan-Meier life-table survival analysis was performed with XLSTAT V7.5.2 software (Addinsoft, New York, NY).

\section{Results}

\section{Early Outcome}

Procedural success. The overall primary technical success rate was $97 \%$ : Stent grafts were deployed successfully in all but 1 patient in whom device tracking was difficult. Endovascular repair was successfully performed in a second intervention 4 days later. The left subclavian artery was covered intentionally in 13 patients for tight proximal fixation and secure device attachment. One patient received an immediate subclavian-carotid bypass after inadvertent partial covering of the left carotid artery resulting from inaccurate placement. No primary conversion or additional simultaneous intervention was needed. The perioperative complication rate was $22 \%$ (cardiac 2, pulmonary 3, retrograde dissection 1, acute renal failure 1, subclavian steal syndrome 1). Paraplegia or stroke was not observed. One patient had subclavian steal syndrome and underwent by-
TABLE 1. Causes of early and late deaths in 37 patients

\begin{tabular}{lcc}
\hline & $\begin{array}{c}\text { Early } \\
\text { deaths }\end{array}$ & $\begin{array}{c}\text { Late } \\
\text { deaths }\end{array}$ \\
\hline $\begin{array}{l}\text { Multiorgan failure, mesenteric ischemia } \\
\text { Multiorgan failure, hepatic failure }\end{array}$ & 3 & \\
Disseminated bleeding disorder & 1 & 1 \\
Infection, sepsis & 1 & \\
Respiratory failure, aspergillosis & 1 & \\
Brain edema, central respiratory failure & 1 & \\
Aortobronchial fistula, hemoptysis & & 1 \\
Cardiac failure & & 2 \\
Infrarenal aortic rupture & & 1 \\
\hline
\end{tabular}

pass grafting 2 days later. The perioperative additional reintervention rate was $13.5 \%$ (acute $18 \%$, chronic $7 \%$ ). Two patients required early aortic reintervention because of retrograde dissection and infrarenal rupture on day 5 (5.4\%). Overall perioperative mortality (30 day) was 19\%, all in acute cases. Multiorgan failure $(n=4)$ as the leading cause of death was observed predominantly in patients with continuing visceral ischemia. Five of 6 patients with TLC and mesenteric ischemia showed a drop of lactate and liver enzymes 12 hours after endovascular entry occlusion, and a return to normal on average 4.5 days after the intervention. A 50-year-old man with TLC and a 2-day history of abdominal pain, primarily treated successfully with immediate re-expansion of the true lumen on completion angiography, developed colon ischemia and multiorgan failure and died 2 days after subtotal colectomy. Two patients with complicated type A dissection died perioperatively; 1 died of respiratory failure and 1 of a bleeding disorder (Table 1). Thirty-day mortality was $10 \%$ for type B dissections and $57 \%$ for type A dissections.

\section{Late Outcome}

Survival. The overall survival at 1, 2, and 5 years after endografting was $81 \%, 64 \%$, and $64 \%$, respectively (Figure 1). There is significant difference $(P=.038)$ in survivals between patients with acute and chronic type B dissections (Table 2, Figure 2). Overall mortality totals $27 \%$. Causes of early and late deaths are listed in Table 1 .

Endoleaks and material fatigue. On postoperative CT scanning, one type II endoleak and one late proximal type I endoleak were diagnosed. This patient, initially treated for CEAD, primarily refused secondary intervention and finally was treated by a proximal extension graft. The proximal endoleak persisted because of a diameter mismatch of the endograft and the aortic arch. The patient died of infrarenal false lumen rupture while she was scheduled for secondary conversion (No. 17). Plain chest radiographs showed no wire form fractures in any patients.

Reintervention. Freedom from aortic reintervention averaged $81 \%, 73 \%$, and $68 \%$ at 1,2 , and 5 years: in acute 


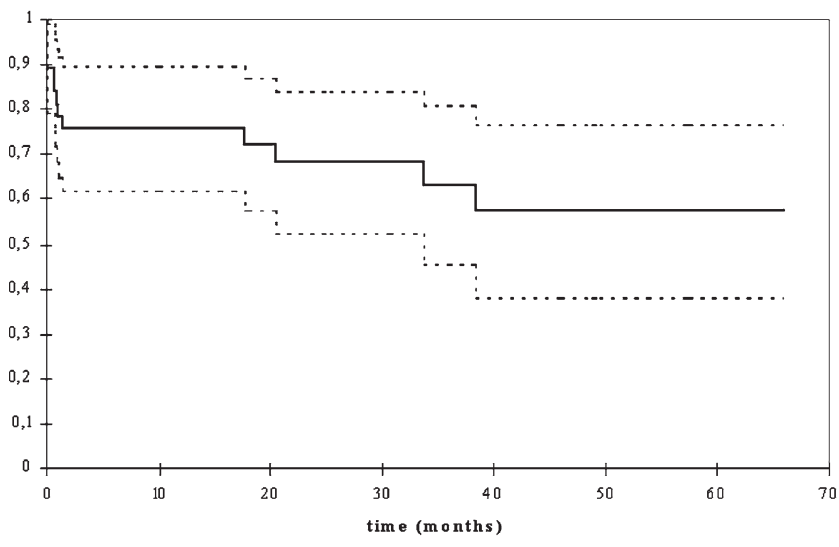

Figure 1. Overall survival rate. $\mathrm{Cl}$, Confidence interval.

cases, $82 \%, 73 \%$, and $73 \%$; in chronic cases, $80 \%, 74 \%$, and $60 \%(P=.412)$ (Figure 3). During follow-up, no conversion (stent-graft explantation) was performed. One secondary proximal type I endoleak was diagnosed. In this patient (No. 17), initially treated for CEAD, a second proximal extension graft was inserted. The proximal endoleak persisted because of a disproportion of the different diameters of the endograft and aortic arch. She died of infrarenal false lumen rupture while she was scheduled for secondary conversion. A 78-year old man (No. 23) with ABF was treated by transfemoral coiling embolization of the false lumen to avoid conversion in a high-risk patient. He died 2 weeks later of another massive hemorrhage. One female patient with Marfan syndrome had chronic visceral aortic expansion and was treated with a hybrid procedure (case discussed later). Two more patients received aorto-biiliac bypass grafting 3 years after stent grafting.

Aortic rupture. Patient 23 had a rupture from the false lumen with $\mathrm{ABF}$ at 18 months. Repetitive hemoptysis after endograft placement was unsuccessfully treated earlier with coil embolization of the false lumen (Figure E1). Patient 17, as reported, had infrarenal rupture just before elective conversion. Actual freedom from rupture was $97 \%, 90 \%$, and $80 \%$ at 1,2 and 3 years, respectively.

False lumen thrombosis. Among 26 survivors, partial false lumen thrombosis of the stented aortic segment was

TABLE 2. Overall survivals of patients with acute, chronic, and overall type $B$ dissection

\begin{tabular}{lccc}
\hline & \multicolumn{3}{c}{ Survival (\%) } \\
\cline { 2 - 4 } & $\mathbf{1}$ year & $\mathbf{2}$ years & $\mathbf{5}$ years \\
\hline Acute & 62 & 62 & 62 \\
Chronic & 100 & 90 & 72 \\
Overall & 81 & 64 & 64 \\
\hline
\end{tabular}

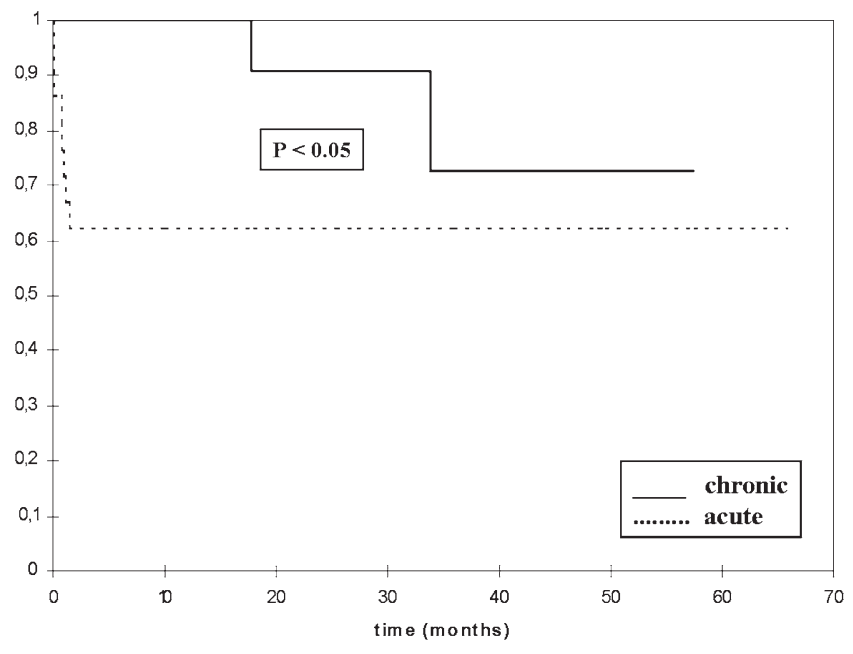

Figure 2. Rates of freedom from procedure-related death in patients with acute and chronic type B dissection.

induced in 7 patients and retrograde perfusion persisted by distal re-entries. Thrombosis of the false lumen of the entire descending thoracic aorta was observed only in 11 patients (44\%). A still patent false lumen was observed in 3 patients.

Chronic abdominal aortic expansion. Overall expansion rate was $32 \%(12 / 37)$ and $48 \%$ among survivors. Only 12 patients (acute, chronic) showed no enlarged aortic diameter during follow-up. Expansion by more than $30 \mathrm{~mm}$ but less than $50 \mathrm{~mm}$ was seen in 7 patients with continuing surveillance by $\mathrm{CT}$ scan. Five patients ( 3 chronic, 2 acute) developed aortic expansion of more than $50 \mathrm{~mm}$ over a 2-year period, and except for 1, all underwent open abdominal aortic bifurcated bypass grafting. One female patient (No. 19) with Marfan syndrome had progressive dilatation of the abdominal aorta after valve replacement and thoracic

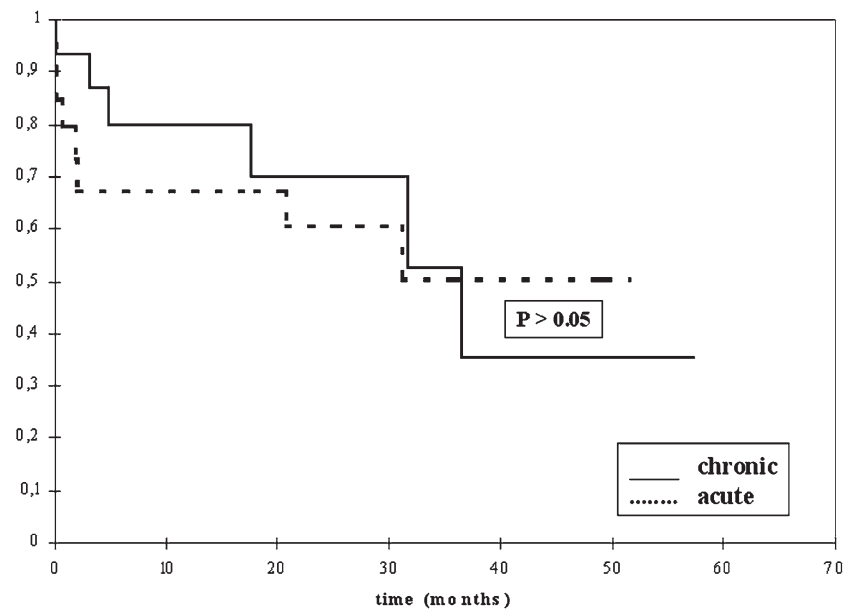

Figure 3. Rates of freedom from secondary interventions. 


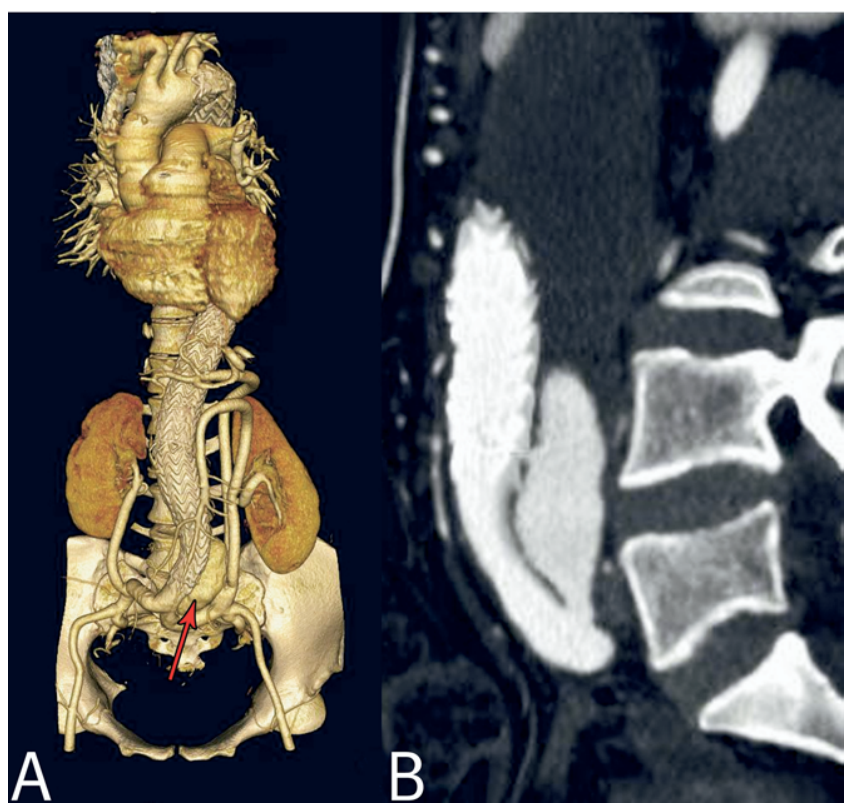

Figure 4. A, Three-dimensional reconstruction of postoperative CT scanning shows patent open retrograde bypass reconstruction of the celiac trunk, superior mesenteric artery, and left renal artery, a separate retrograde revascularization of the right renal artery (8-mm Dacron graft), and complete endovascular repair of the thoracoabdominal aneurysmal expanded aorta with 4 TAG devices (28-100 and 31-150 mm in reversed thrombone technique). B, Retrograde false lumen reperfusion is still documented, originating from the left common iliac artery.

endografting of the distal arch. In a staged hybrid procedure, she was treated by extra-anatomic mesenteric and renal revascularization and endografting of the thoracoabdominal aorta (Figure 4).

Total treatment failure. Actual freedom from all postoperative events (treatment failure including death) was $76 \%, 65 \%$, and $57 \%$ at 1,2 , and 5 years, respectively. Patients with chronic dissections do significantly $(P=.034)$ better than those with acute dissections $(64 \%, 50 \%$, and $45 \%$ vs $93 \%, 87 \%$, and $73 \%$ ) (Figure 5).

\section{Discussion}

Aortic treatment paradigms have evolved with the development of endovascular stent-graft repair of thoracic aortic aneurysms, which started at Stanford in 1992. ${ }^{10}$ The same authors published the only available study describing midterm results (4.5 years) of endovascular stent-graft repair of a thoracic aneurysm. ${ }^{11}$ Although there are no long-term data to support definitive evidence, endovascular treatment is also proposed as an alternative therapy in patients with type $\mathrm{B}$ dissections. Whether stent grafting provides lasting protection from aortic rupture (especially false lumen rupture),

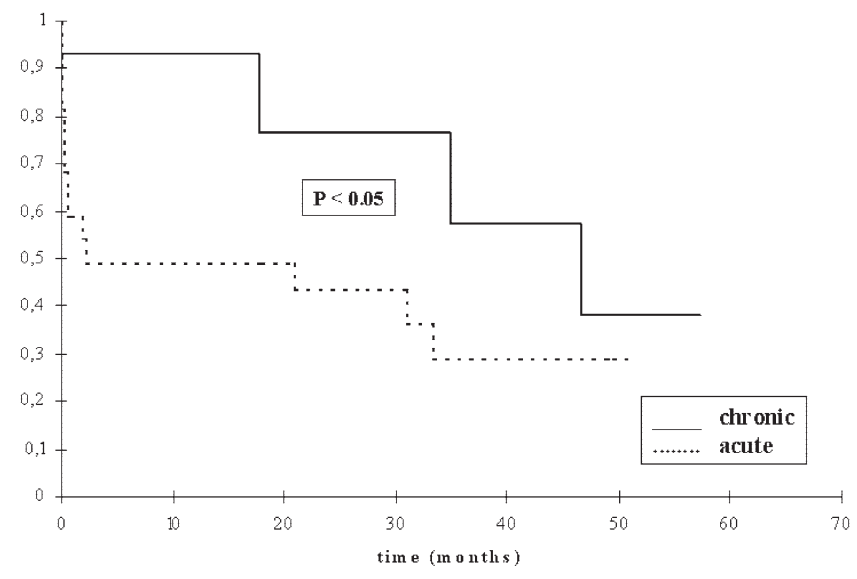

Figure 5. Rates of freedom from any adverse event (treatment failure).

from chronic aortic expansion, or from end organ ischemia still has to be determined. Therefore, we analyzed our midterm results for endovascular therapy on patients with type B aortic dissections.

The specific findings of this study highlight the problems and open questions of endovascular treatment in aortic dissections: The 30-day mortality rate of acute type B dissections after endograft implantation is still high (19\%); in type A dissections it is as high as 57\%. These disparate mortality rates likely pertain to patient selection bias and the acuity or pretreatment physiologic status of the patients. The high percentage of emergency interventions in this study (59\%) and no diagnosis or delayed diagnosis of visceral ischemia in the prehospital time period may be a cause for patients dying of multiorgan failure despite technically successful entry closure. Many authors have published results on transluminal placement of endovascular stent grafts for the treatment of descending thoracic aortic dissections (Table 3). ${ }^{12-14}$ Dake and associates ${ }^{4}$ reported a series of 19 acute symptomatic dissections with $16 \%$ early mortality. This is in line with the $19 \%$ mortality in our own series. Early mortality in a third study from Palma and coworkers ${ }^{15}$ published an early mortality of $6 \%$ in 58 patients, and of those, 35 had acute dissection but were asymptomatic. A comparative study of both therapy modalities, "endovascular versus conservative," for uncomplicated courses of asymptomatic patients is currently running. The excellent results achieved in 82 patients by Rehders and Nienhaber ${ }^{16}$ are difficult to interpret because of a lack of differentiation between acute and chronic dissections, ruptures, and ischemia. Frequently, no difference between the results of asymptomatic and symptomatic patients has been made. Numerous retrospective studies with univariate and multivariate data analysis have been carried out to 
TABLE 3. Selected literature review of endovascular therapy in patients with Stanford type A/B dissections

\begin{tabular}{|c|c|c|c|c|c|c|}
\hline First author & Patients (n) & Type of dissection & $\begin{array}{c}\text { Technical } \\
\text { success (\%) }\end{array}$ & $\begin{array}{c}\text { Thirty-day } \\
\text { mortality rate }\end{array}$ & $\begin{array}{c}\text { Major } \\
\text { complications }\end{array}$ & $\begin{array}{c}\text { Mean } \\
\text { follow-up (mo) }\end{array}$ \\
\hline Dake $(1999)^{4}$ & 19 & A 4 B 15 & 100 & $3 / 19$ & $4 / 19$ & $4-28$ \\
\hline Nienhaber $(1999)^{5}$ & 12 & A 0 B 12 & 100 & $0 / 12$ & - & 12 \\
\hline Rehders $(1999)^{16}$ & 94 & - & 100 & $0 / 94$ & $5 / 94$ & 12 \\
\hline Ince $(2000)^{26}$ & 120 & - & 98 & $2 / 120$ & - & 12 \\
\hline Lonn $(2002)^{27}$ & 41 & - & 87.8 & - & - & $1-19$ \\
\hline Orendt $(2003)^{19}$ & 14 & B 14 & 100 & $0 / 14$ & $9 / 14$ & 22 \\
\hline Own series (2004) & 37 & $\begin{array}{l}\text { A } 7 \text { (with descending tear, } \\
\text { symptomatic) B } 30\end{array}$ & 92 & $4 / 73 / 30$ & $13 / 37$ & 22 \\
\hline
\end{tabular}

define those initial factors of the acute phase that determine the clinical course and the long-term prognosis. ${ }^{5,17}$ Mesenteric ischemia has a major impact on outcome. Two of our patients died of multiorgan failure because of visceral ischemia and unresolved malperfusion persisting postoperatively. One 48-year-old male patient (No. 27), who was stent grafted with clinically asymptomatic abdomen but occlusion of the celiac trunk and superior mesenteric artery, developed severe colon ischemia and died despite early entry closure within 48 hours. Malperfusion remains a major challenge. If mesenteric ischemia is suspected, an aggressive posture toward laparotomy or laparoscopy is appropriate, even if endovascular revascularization has been achieved. Following laboratory values for potential markers of mesenteric infarction can be crucial. Four of our patients died because of delayed recognition.

Long-term data suggest that up to $40 \%$ of asymptomatic patients will die of aorta-related causes or require a direct aortic reintervention over a 7 -year period. ${ }^{18}$ Thirty percent to $40 \%$ of all symptomatic patients have complications over the further clinical course. ${ }^{1}$ Consequently, achievement of complete false lumen thrombosis and prevention of aortic growth and expansion is the main goal in the treatment of dissections. We observed complete or false lumen thrombosis only in $44 \%$ of patients and severe visceral aortic expansion over $50 \mathrm{~mm}$ in 5 patients. In the series reported by Kato and associates, ${ }^{17}$ only $38.5 \%$ of chronic dissections showed complete obliteration during 27 months of follow-up.

Patients after type A repair and residual type B dissections are also potential candidates for "hybrid" distal stent grafting. The 30-day mortality of this approach in our series of $57 \%$ is closely related to complications after type A repair, to a sick and small cohort of 5 patients, and needs skeptical judgment. The strategy of immediate hybrid repair of the ascending and descending aorta including technical considerations of antegrade versus retrograde stent-graft deployments needs definitive future evaluation.
Spinal cord ischemia after stent-graft repair of dissections varies between $3 \%$ and $10 \%$ in the literature, ${ }^{19} 0 \%$ in this study. ${ }^{19}$ Potential factors for the lower incidence of spinal cord ischemia during endovascular repair are adequate collateral blood supply, no aortic crossclamping, short extension of stent graft-covered aorta, and deployment positioning far from the suggested origin of the artery of Adamkiewicz.

Sufficient proximal anchoring of $2 \mathrm{~cm}$ is necessary to avoid a proximal type I endoleak. To achieve this, coverage of the left subclavian or combined conventional transposition of the aortic arch branches may be necessary (Figure E2). We covered the left subclavian artery in 13 patients. One patient had clinically moderate dizziness and was observed without secondary intervention. Two patients had a proximal type I endoleak. Causes were incorrect endograft sizing and inflexible devices for the distal arch, which did not properly seal the proximal anchoring zone. Proximal tight fixation in the distal arch is mandatory and mostly makes covering the left subclavian artery necessary.

The importance of the chronic expansion and the factors of influence have been the subject matter of numerous studies. ${ }^{17}$ An initial diameter of more than 4 $\mathrm{cm}$ and a persistent entry into the false lumen have been identified as determinants for CEAD. Surgical intervention rate and associated mortality is reported to be high $(30 \%-40 \%) .{ }^{20}$ Overall expansion rate was $32 \%(12 / 37)$, and $48 \%$ among survivors in this study underlines this significant sequelae.

Asymptomatic patients with an open false lumen, an initially large aortic diameter greater than $40 \mathrm{~mm}$, and ongoing "open entry" face unfavorable prognostic factors. ${ }^{21}$ The 1 -year and 5-year survivals of asymptomatic patients under conservative medication amount to $94 \%$ and $86 \%$, respectively. A comparison of these patients, however, to others who have undergone surgical therapy with a significantly higher risk is not permissible.

In a multicenter study comprising 465 patients, Hagan and associates $^{2}$ report a 3 times higher postoperative 
mortality rate $(31.4 \%)$ as compared with the conservative patient group (10.7\%). Lansmann and colleagues, ${ }^{22}$ however, report a mortality of $0 \%$ with a fairly high associated complication rate of $47 \%$ in 34 patients with symptomatic type B dissection who had undergone surgery in the acute phase. In 1999, Nienhaber and colleagues ${ }^{5}$ published a small study that was the first prospective study to compare transluminal and open surgery, constituting that stent-graft repair is a viable therapeutic option.

\section{Limitations}

Further unanswered questions are the spontaneous course of an asymptomatic radiologic "TLC" and its potential influencing factors, which determine the fate of the true lumen. Experimental studies carried out by Chung and associates ${ }^{23,24}$ could prove the effectiveness of overstenting the intimal rupture site ("entry") for treatment of TLC. However, as long-term results are still lacking, it remains to be seen whether this circumstance can be classified as a criterion of success or aim of therapy. After 2 years, false lumen thrombosis rate was only $44 \%$. Persisting perfusion of the false channel correlates with late complications CEAD and death due to rupture. ${ }^{23,24}$ The meaning of patent false lumen in the further clinical course remains an open question. The term "true lumen collapse" (TLC) is difficult to interpret, as dissections are dynamic events with membrane movements, which can clearly be demonstrated by cine magnetic resonance imaging. The development of a specific endograft design for dissection therapy will become necessary. There is no ideal stent graft for dissections yet. The characteristics needed are gentle and flexible design, with no radial force and no bare springs. An important issue is the rigidity of the systems, which can cause penetration of the thin membrane. Of all the commercially available thoracic devices (Talent, Excluder, Endofit, and Zenith [Cook Incorporated, Bloomington, Ind]), we prefer the Excluder endoprosthesis, because of its access size and good flexibility. Finally, proof of the concept that endografts prevent long-term complications requires a prospective randomized trial. Our own therapy concept provides endovascular treatment in the symptomatic acute stage (any kind of ischemia, symptomatic TLC) or during the chronic course with aneurysmal expansion of more than $55 \mathrm{~mm} .{ }^{22}$ Therefore, only $23 \%$ of 110 patients with Stanford type B dissection were selected for endovascular surgery.

\section{Conclusion}

In summary, the concept of endoluminal entry occlusion in acute or symptomatic type B dissections is promising and represents at least an alternative method of choice in symptomatic type B dissections. However, long-term fol- low-up data are required and caution is needed using endovascular therapy, especially in asymptomatic patients. Of paramount importance is the reporting of complications. According to our results, we continue to be restricted with thoracic endografting in dissections. We do not treat asymptomatic patients with uncomplicated courses and CEAD until the aortic diameter reaches more than $55 \mathrm{~mm} .{ }^{25}$ The concept of endovascular treatment of type B dissections should be subjected to randomized evaluation to settle all the answers.

\section{References}

1. Meszaros I, Morocz J, Szlavi J, Schmidt J, Tomoci L, Nagy L, et al. Epidemiology and clinicopathology of aortic dissection. Chest. 2000; 117:1271-8

2. Hagan PG, Nienaber CA, Isselbacher EM, Bruckman D, Karavite DJ, Russman PL, et al. The International Registry of Acute Aortic Dissection (IRAD): new insights into an old disease. JAMA. 2000;283: 897-903.

3. Safi HJ, Miller CC III, Subramaniam MH, Campbell MP, Iliopoulos DC, O'Donnell JJ, et al. Thoracic and thoracoabdominal aneurysm repair using cardiopulmonary bypass, profound hypothermia and circulatory arrest via left side of the chest incision. J Vasc Surg. 1998; 28:591-8.

4. Dake MD, Kato N, Mitchell RS, Semba CP, Razavi MK, Shimono T, et al. Endovascular stent-graft placement for the treatment of acute aortic dissection. N Engl J Med. 1999;340:1546-52.

5. Nienhaber CA, Fattori R, Lund G, Dieckmann C, Wolf W, von Kodolitsch Y, et al. Non-surgical reconstruction of thoracic aortic dissection by stent-graft placement. N Engl J Med. 1999;340:1539-45.

6. Hansen CJ, Bui H, Donayre CE, Abiz I, Kim B, Kopchok G, et al. Complications after endovascular repair of high-risk and emergent descending thoracic aortic aneurysms and dissections. J Vasc Surg. 2004;40:228-34.

7. Pamler RS, Kotsis T, Görich J, Kapfer X, Orend KH, Sunder-Plassmann L. Complications after endovascular repair of type B aortic dissection. $J$ Endovasc Ther. 2002;9:822-8.

8. Cambria R, Brewster D, Gertler J, Moncure A, Gusberg R, Tilson M. Vascular complications associated with spontaneous aortic dissections. J Vasc Surg. 1988;7:199-209.

9. Chaikof EL, Blankensteijn JD, Harris PL, White GH, Zarins CK, Bernhard VM, et al. Reporting standards for endovascular aortic aneurysm repair. J Vasc Surg. 2002;35:1048-60.

10. Dake MD, Miller DC, Semba CP, Mitchell RS, Walker PJ, Liddell RP. Transluminal placement of endovascular stent-grafts for the treatment of descending thoracic aortic aneurysms. N Engl J Med. 1994;331: 1729-34.

11. Demers P, Miller DC, Mitchell RS, Kee ST, Sze D, Razavi MK, et al. Midterm results of endovascular repair of descending thoracic aortic aneurysms with the first-generation stent grafts. $J$ Thorac Cardiovasc Surg. 2004;127:664-73.

12. Beregi J-P, Haulon S, Otal P, Thony F, Bartoli JM, Crochet D, et al. Endovascular treatment of acute complications associated with aortic dissection: Midterm results from a multicenter study. J Endovasc Ther. 2003;10:486-93.

13. Bell RE, Taylor PR, Aukett M, Sabharwal T, Reidy JF. Results of urgent and emergency thoracic procedures treated by endoluminal repair. Eur J Vasc Endovasc Surg. 2003;25:527-31.

14. Matravers P, Morgan R, Bell A. The use of stent grafts for the treatment of aneurysms and dissections in the thoracic aorta: a single centre experience. Eur J Vasc Endovasc Surg. 2003;26:587-95.

15. Palma JH, de Souza JAM, Rodrigues Alves CM, Carvalho AC, Buffolo E. Self-expandable aortic stent-grafts for treatment of descending aortic dissections. Ann Thorac Surg. 2002;73:1138-42.

16. Rehders TC, Nienhaber CA. Complications of stent graft placement in the thoracic aorta. In: Branchereau A, Jacobs M, editors. Complica- 
tions in vascular and endovascular surgery. Armonk [NY]: Futura Publishing Co; 2001. p. 85-192.

17. Kato M, Bai H, Sato K, Kawamoto S, Kaneko M, Ueda T, et al. Determining surgical indications for acute type B dissection based on enlargment of aortic diameter during the chronic phase. Circulation. 1995;92 (Suppl):II107-12.

18. DeBakey M, McCollum C, Crawford E, Morris G, Howell J, Noon G, et al. Dissection and dissecting aneurysms of the aorta: twenty year follow-up of five hundred twenty-seven patients treated surgically. Surgery. 1982;92:1118-34.

19. Orendt KH, Scharrer-Pamler R, Kapfer X, Kotsis T, Gorich J, SunderPlassmann L. Endovascular treatment in diseases of the descending thoracic aorta: 6-year results of a single center. J Vasc Surg. 2003;37:91-9.

20. Juvonen T, Ergin MA, Galla JD, Lansman SL, McCullough JN, Nguyen K, et al. Risk factors for rupture of chronic type B-dissections. J Thorac Cardiovasc Surg. 1999;117:776-86.

21. Kozai Y, Watanabe S, Yonezawa M, Itani Y, Inoue T, Takasu J, et al. Long-term prognosis of acute aortic dissection with medical treatment: a survey of 263 unoperated patients. Jpn Circ J. 2001;65:359-63.

22. Lansman SG, Hagl C, Fink D, Galla JD, Spielvogel D, Ergin MA, et al. Acute type B dissection: surgical therapy. Ann Thorac Surg. 2002;74:S1833-5.

23. Chung JW, Elkins C, Sakai T, Kato N, Vestring T, Semba CP, et al. True-lumen collapse in aortic dissection: part I. Evaluation of causative factors in phantoms with pulsatile flow. Radiology. 2000;214:87-98.

24. Chung JW, Elkins C, Sakai T, Kato N, Vestring T, Semba CP, et al. True-lumen collapse in aortic dissection: part II. Evaluation of treatment methods in phantoms with pulsatile flow. Radiology. 2000;214: 99-106.

25. Bockler D, Schumacher H, Ockert S, Schwarzbach M, Klemm K, Hansmann J, et al. Acute and chronic expanding type B dissection: what is the impact of endografts on indications for treatment? Gefaesschirurgie. 2003;8:192-9.

26. Ince H, Rehders TC, Nienaber CA. Thoracic aneurysms and type B dissections should be treated by stent-graft-for the motion. In: Greenhalgh RM, editor. The evidence for vascular and endovascular reconstruction. Philadelphia: W.B. Saunders, Elsevier Science Limited; 2002. p. 119-25.

27. Lonn L, Delle M, Lepore V. Endograft therapy of the thoracic aorta in aortic dissections. Cardiovasc Intervent Radiol. 2002;25(Suppl):164-71.

\section{Online-www.aats.org}

Now you can get The Journal of Thoracic and Cardiovascular Surgery online. The Journal online brings you faster delivery time, easy searching of current and back issues, links to PubMed, AATS, WTSA, and other important sites, and more. Visit the Journal online today.

\section{Receive tables of contents by e-mail}

To receive the tables of contents by e-mail, sign up through our Web site at http://journals.elsevierhealth.com/periodicals/ymtc Choose E-mail Notification Simply type your e-mail address in the box and click the Subscribe button. You will receive an e-mail to confirm that you have been added to the mailing list. Note that TOC e-mails will be sent out when a new issue is posted to the Web site. 


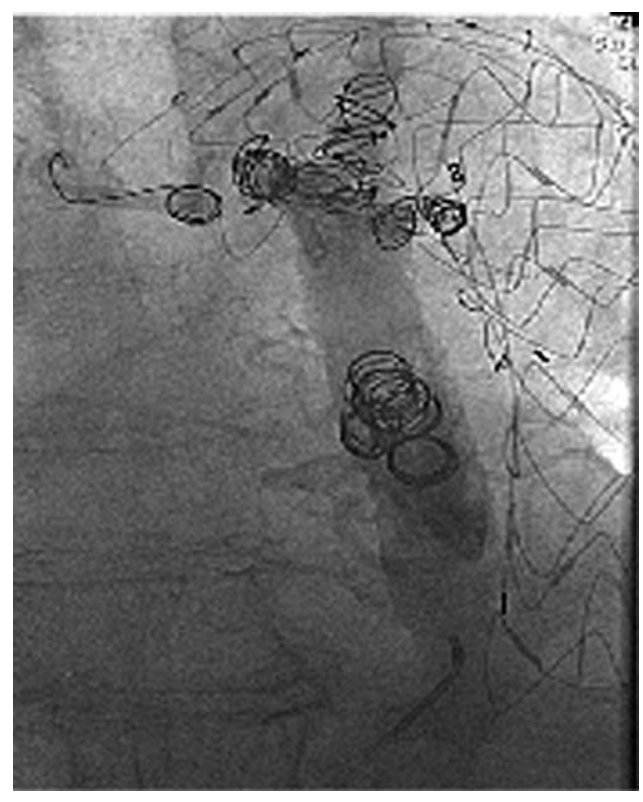

Figure E1. Postembolization chest radiography in a patient who had hemoptysis due to ABF 17 months after successful stent-graft placement for aortic dissection. Coils were placed into the false lumen above and below the detected and localized fistula tract.

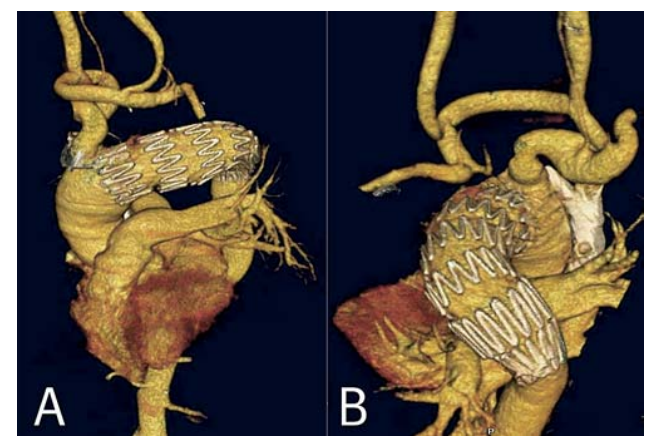

Figure E2. Postoperative 3-dimensional reconstruction (Vitrea, Vital Images) after transposition and crossover bypass grafting of supra-aortic vessels and staged distal arch endografting to create a suitable neck for proximal stentgraft fixation. A, Anterior view. B, Posterior view (patent No. 34). 
TABLE E1. Patient characteristics of 37 patients treated with endovascular stent graft placement for acute complicated or chronic expanding aortic type B dissection (numbered consecutively to procedure date out of total 112 patients with thoracic endografting)

\begin{tabular}{|c|c|c|c|c|c|c|}
\hline $\begin{array}{l}\text { No./ } \\
\text { consecutive } \\
\text { patient }\end{array}$ & $\begin{array}{l}\text { Age }(y) / \\
\text { sex }\end{array}$ & $\begin{array}{l}\text { Acute (emergency) or } \\
\text { chronic } \\
\text { (elective)/indication }\end{array}$ & $\begin{array}{c}\text { Endograft } \\
\text { model/size/No. } \\
\text { of grafts }\end{array}$ & $\begin{array}{c}\text { AICA: } \pm / \text { covered left } \\
\text { subclavian/simultaneous } \\
\text { conventional procedures }\end{array}$ & Complications & Outcome \\
\hline $3 / 22$ & 71/M & Acute/TLC, AAA $56 \mathrm{~mm}$ & TAG/28-100/1 & $+/$ no/no & $\begin{array}{l}\text { Acute coronary } \\
\text { syndrome, PTCA } \\
\text { and stenting on } \\
\text { day } 3\end{array}$ & Alive at $49 \mathrm{mo}$ \\
\hline $5 / 28$ & $61 / \mathrm{M}$ & $\begin{array}{l}\text { Chronic/prevention of } \\
\text { rupture-CEAD (60 } \\
\text { mm), previous } \\
\text { ascending }+ \text { arch } \\
\text { replacement }\end{array}$ & TAG/34-125/1 & $\begin{array}{l}\text {-/no/aorto-biiliac } \\
\text { bypass }\end{array}$ & & Alive at $47 \mathrm{mo}$ \\
\hline $6 / 32$ & $62 / \mathrm{M}$ & $\begin{array}{l}\text { Chronic/CEAD- } \\
\text { prevention of rupture/ } \\
\text { previous ascending }+ \\
\text { arch replacement }\end{array}$ & TAG/40-200/1 & +/yes/no & & Alive at $43 \mathrm{mo}$ \\
\hline $7 / 33$ & $58 / \mathrm{M}$ & $\begin{array}{l}\text { Chronic/CEAD, } \\
\text { prevention of rupture }\end{array}$ & TAG/34-200/1 & +/no/no & & Alive at $43 \mathrm{mo}$ \\
\hline $10 / 40$ & $44 / F$ & $\begin{array}{l}\text { Acute/TLC, ischemia left } \\
\text { kidney, right leg }\end{array}$ & TAG/34-200/1 & +/yes/no & & Alive at $41 \mathrm{mo}$ \\
\hline $11 / 42$ & 78/M & Acute/rCEAD & $\begin{array}{l}\text { TAG/28-150, } \\
34-150,40- \\
150 \text { rev. } \\
\text { trombone/3 }\end{array}$ & +/no/no & $\begin{array}{l}\text { Endoleak type II, } \\
\text { pleural effusion }\end{array}$ & Alive at $37 \mathrm{mo}$ \\
\hline $12 / 43$ & $58 / \mathrm{M}$ & $\begin{array}{l}\text { Acute/TLC, visceral } \\
\text { ischemia }\end{array}$ & $\begin{array}{l}\text { TAG/34-200, } \\
34-100 \\
\text { thrombone/2 }\end{array}$ & $+/$ no/no & & Alive at $32 \mathrm{mo}$ \\
\hline $13 / 46$ & $41 / \mathrm{M}$ & Acute/Ehlers-Danlos & TAG/37-200/1 & $-/$ no/no & & Alive at $39 \mathrm{mo}$ \\
\hline $14 / 47$ & $62 / \mathrm{M}$ & Acute/visceral ischemia & TAG/34-200/1 & -/no/tube graft & & Alive at $39 \mathrm{mo}$ \\
\hline $15 / 49$ & $62 / F$ & $\begin{array}{l}\text { Chronic/CEAD (65 mm), } \\
\text { prevention of rupture }\end{array}$ & $\begin{array}{l}\text { TAG/34-200, } \\
34-150 \\
\text { thrombone/2 }\end{array}$ & $+/$ no/no & $\begin{array}{l}\text { Proximal endoleak } \\
\text { type I, } \\
\text { progressive } \mathrm{FL}, \\
\text { expansion, } \\
\text { second proximal } \\
\text { endograft }\end{array}$ & $\begin{array}{l}\text { Died at } 21 \text { mo of } \\
\text { infrarenal } \\
\text { rupture and } \\
\text { persisting } \\
\text { endoleak, while } \\
\text { waiting for } \\
\text { conversion }\end{array}$ \\
\hline
\end{tabular}


TABLE E1. Continued

\begin{tabular}{|c|c|c|c|c|c|c|}
\hline $\begin{array}{l}\text { No./ } \\
\text { consecutive } \\
\text { patient }\end{array}$ & $\begin{array}{c}\text { Age }(y) / \\
\operatorname{sex}\end{array}$ & $\begin{array}{c}\text { Acute (emergency) or } \\
\text { chronic } \\
\text { (elective)/indication }\end{array}$ & $\begin{array}{c}\text { Endograft } \\
\text { model/size/No. } \\
\text { of grafts }\end{array}$ & $\begin{array}{c}\text { AICA: } \pm / \text { covered left } \\
\text { subclavian/simultaneous } \\
\text { conventional procedures }\end{array}$ & Complications & Outcome \\
\hline $16 / 51$ & $68 / \mathrm{M}$ & Chronic/CEAD (mm) & TAG/37-150/1 & +/no/no & & Alive at $39 \mathrm{mo}$ \\
\hline $17 / 52$ & $32 / F$ & Acute/Marfan & TAG/31-150/1 & +/no /no & & $\begin{array}{l}\text { Alive at } 36 \text { mo. } \\
\text { Distal aortic } \\
\text { expansion, } \\
\text { treated with } \\
\text { hybrid } \\
\text { procedure }\end{array}$ \\
\hline $18 / 60$ & $80 / \mathrm{M}$ & Acute & TAG/37-150/1 & +/yes/no & $\begin{array}{l}\text { Aspergillosis, } \\
\text { long-term } \\
\text { ventilation }\end{array}$ & $\begin{array}{l}\text { Died at } 0.6 \text { mo of } \\
\text { respiratory } \\
\text { failure }\end{array}$ \\
\hline $19 / 65$ & $46 / \mathrm{M}$ & $\begin{array}{l}\text { Acute/visceral ischemia } \\
\text { and right leg ischemia }\end{array}$ & TAG/34-150/1 & +/yes/no & $\begin{array}{c}\text { Pneumonia, } \\
\text { delirium }\end{array}$ & Alive at $26 \mathrm{mo}$ \\
\hline $20 / 73$ & $62 / \mathrm{M}$ & $\begin{array}{l}\text { Chronic/CEAD- } \\
\text { prevention of rupture } \\
(80 \mathrm{~mm})\end{array}$ & $\begin{array}{l}\text { Endofit/38-220- } \\
\quad 24 / 1\end{array}$ & $\begin{array}{l}\text { +/yes/subclavian- } \\
\text { carotid bypass }\end{array}$ & $\begin{array}{l}\text { Inadvertent partial } \\
\text { covering of the } \\
\text { left carotid } \\
\text { ostium }\end{array}$ & Alive at $20 \mathrm{mo}$ \\
\hline $21 / 74$ & 78/M & $\begin{array}{l}\text { Chronic/CEAD (55 mm) } \\
\text { and ABF }\end{array}$ & $\begin{array}{c}\text { Talent/40-115, } \\
42-115-40 / 2\end{array}$ & +/yes/no & $\begin{array}{l}\text { Persisting } A B F \text {, } \\
\text { secondary } \\
\text { endografting, } \\
\text { selective coiling } \\
\text { of the FL }\end{array}$ & $\begin{array}{l}\text { Died at } 18 \text { mo of } \\
\text { massive } \\
\text { hemoptysis }\end{array}$ \\
\hline $22 / 79$ & $67 / \mathrm{M}$ & Acute/Marfan & Talent/36-130/2 & -/no/renal stenting & & Alive at $18 \mathrm{mo}$ \\
\hline $23 / 80$ & $63 / \mathrm{M}$ & $\begin{array}{l}\text { Acute/penetrating aortic } \\
\text { ulcer }\end{array}$ & $\begin{array}{l}\text { Talent/36-130 } \\
\text { thrombone/2 }\end{array}$ & +/yes/no & & Alive at $17 \mathrm{mo}$ \\
\hline $24 / 83$ & $82 / F$ & $\begin{array}{l}\text { Acute/TLC, renal and } \\
\text { leg ischemia }\end{array}$ & Talent/36-130/1 & -/yes/no & $\begin{array}{l}\text { Persisting visceral } \\
\text { ischemia }\end{array}$ & $\begin{array}{l}\text { Died on day } 1 \text { of } \\
\text { MOF }\end{array}$ \\
\hline $25 / 85$ & 48/M & Acute/visceral ischemia & Talent/34-130/1 & $+/$ no/no & Colon ischemia & $\begin{array}{l}\text { Died on day } 3 \text { of } \\
\text { MOF }\end{array}$ \\
\hline $26 / 91$ & $60 / \mathrm{M}$ & $\begin{array}{c}\text { Chronic/CEAD }(55 \mathrm{~mm}) / \\
\text { renal cell carcinoma }\end{array}$ & TAG 34-150/1 & $+/$ no/no & & Alive at 9 mo \\
\hline $27 / 93$ & $60 / \mathrm{M}$ & Chronic/CEAD (50 mm) & TAG/34-200/1 & +/no/no & & Alive at 9 mo \\
\hline $28 / 96$ & $61 / \mathrm{M}$ & Chronic/CEAD (55 mm) & TAG/34-150/1 & $-/$ no/no & & Alive at $8 \mathrm{mo}$ \\
\hline 29/97 & $65 / \mathrm{M}$ & $\begin{array}{l}\text { Acute/CEAD, contained } \\
\text { rupture } \mathrm{FL}, \\
\text { hemothorax }\end{array}$ & TAG/34-200/1 & -/yes/no & $\begin{array}{l}\text { Acute renal } \\
\text { failure, } \\
\text { hemodialysis, } \\
\text { comatose } \\
\text { tracheal } \\
\text { respiration }\end{array}$ & Alive at $8 \mathrm{mo}$ \\
\hline $30 / 100$ & $48 / F$ & $\begin{array}{l}\text { Chronic/CEAD- } \\
\text { prevention of rupture } \\
(60 \mathrm{~mm})\end{array}$ & Talent/26-130/1 & $-/$ no/no & & Alive at $6 \mathrm{mo}$ \\
\hline $31 / 102$ & $50 / \mathrm{M}$ & $\begin{array}{l}\text { Chronic/CEAD }(\mathrm{mm}), \mathrm{FL} \\
\text { rupture before, } \\
\text { conventional repair; } \\
\text { primary suturing }\end{array}$ & $\mathrm{TAG} / 40-200 / 1$ & +/yes/no & & Alive at $5 \mathrm{mo}$ \\
\hline $32 / 105$ & $50 / \mathrm{M}$ & $\begin{array}{l}\text { Chronic/CEAD }(48 \mathrm{~mm}) \\
\text { and large left } \\
\text { subclavian artery } \\
\text { aneurysm }\end{array}$ & TAG/37-150/1 & +/yes/yes & $\begin{array}{l}\text { Thoracotomy, } \\
\text { major bleeding }\end{array}$ & Alive at $3 \mathrm{mo}$ \\
\hline
\end{tabular}


TABLE E1. Continued

\begin{tabular}{|c|c|c|c|c|c|c|}
\hline $\begin{array}{l}\text { No./ } \\
\text { consecutive } \\
\text { patient }\end{array}$ & $\begin{array}{c}\text { Age }(y) / \\
\operatorname{sex}\end{array}$ & $\begin{array}{c}\text { Acute (emergency) or } \\
\text { chronic } \\
\text { (elective)/indication }\end{array}$ & $\begin{array}{c}\text { Endograft } \\
\text { model/size/No. } \\
\text { of grafts }\end{array}$ & $\begin{array}{c}\text { AICA: } \pm / \text { covered left } \\
\text { subclavian/simultaneous } \\
\text { conventional procedures }\end{array}$ & Complications & Outcome \\
\hline $33 / 108$ & $78 / F$ & Chronic/CEAD (62 mm) & TAG/34-200/1 & +/yes/no & $\begin{array}{l}\text { Postoperative } \\
\text { asystole, } \\
\text { successful } \\
\text { reanimation, } \\
\text { hypovolemia }\end{array}$ & Alive at $2 \mathrm{mo}$ \\
\hline $34 / 112$ & $61 / \mathrm{M}$ & $\begin{array}{l}\text { Acute/persistent chest } \\
\text { pain, diameter at } \\
\text { entry site: } 52 \mathrm{~mm}\end{array}$ & TAG/34-200/1 & +/yes/no & & Alive at $0.5 \mathrm{mo}$ \\
\hline $35 / 105$ & $50 / \mathrm{M}$ & $\begin{array}{l}\text { Chronic/CEAD (48 mm) } \\
\text { and large left } \\
\text { subclavian artery } \\
\text { aneurysm }\end{array}$ & TAG/37-150/1 & +/yes/yes & $\begin{array}{l}\text { Thoracotomy } \\
\text { major bleeding }\end{array}$ & Alive at 3 month \\
\hline $36 / 108$ & $78 / F$ & Chronic/CEAD (62 mm) & TAG/34-200/1 & +/yes/no & $\begin{array}{l}\text { Postoperative } \\
\text { asystole, } \\
\text { successful } \\
\text { reanimation, } \\
\text { hypovolemia }\end{array}$ & Alive at $2 \mathrm{mo}$ \\
\hline $37 / 112$ & $61 / \mathrm{M}$ & $\begin{array}{l}\text { Acute/resistant chest } \\
\text { pain, diameter at } \\
\text { entry site: } 52 \mathrm{~mm}\end{array}$ & TAG/34-200/1 & +/yes/no & & Alive at $0.5 \mathrm{mo}$ \\
\hline
\end{tabular}

$C E A D$, Chronic expanding aortic dissection; $r C E A D$, ruptured; $T L C$, true lumen collapse; $M O F$, multiorgan failure; $F L$, false lumen; $A B F$, aortobronchial fistula. 